\title{
SPRING 2013
}

\section{The}

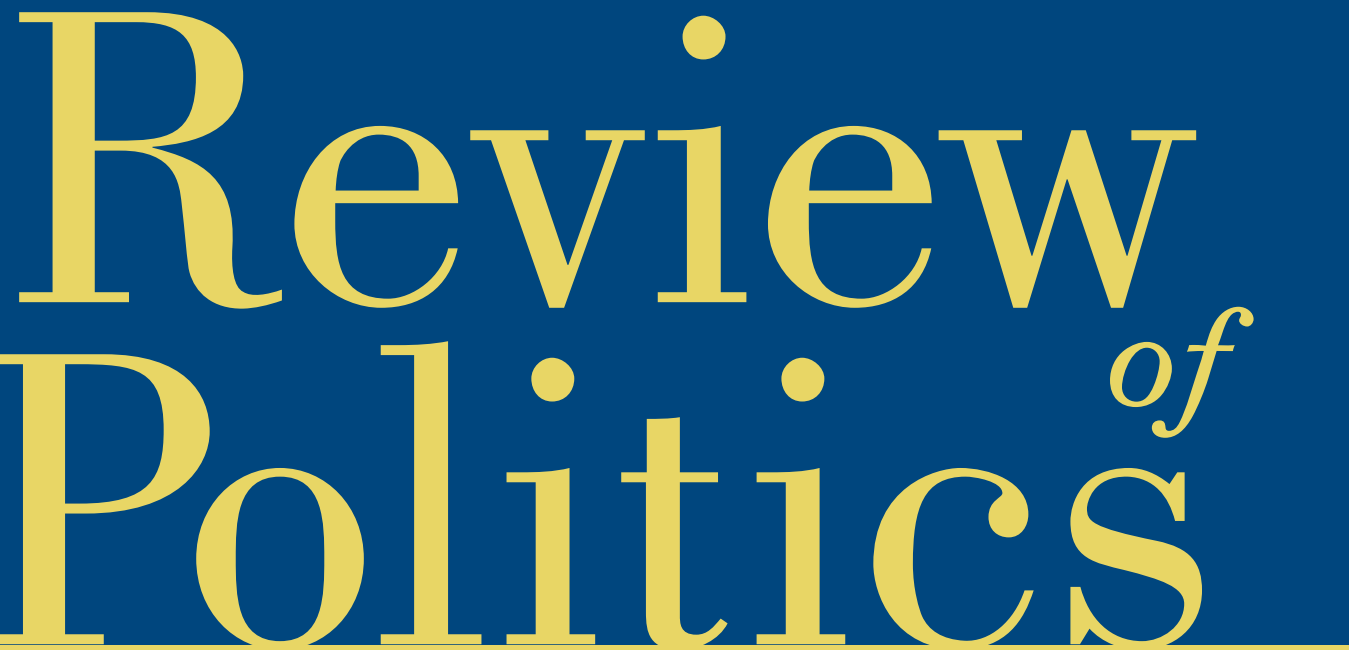

A RTICLES

John Baltes, "Locke’s Inverted Quarantine: Discipline, Panopticism, and the Making of the Liberal Subject"

Jonathan Culp, "Justice, Happiness, and the Sensible Knave:

Hume's Incomplete Defense of the Just Life"

Laura K. Field, "The Philosopher Doth Protest Too Much:

Rousseauian Enlightenment and the Rhetoric of Despair"

Michael Locke McLendon, "The Politics of Sour Grapes: Sartre, Elster, and Tocqueville on Frustration, Failure, and Self-Deception" 


\section{THE REVIEW OF POLITICS}

Editor

CATHERINE H. ZUCKERT

Executive Associate Editor

DENNIS WM MORAN

Book Review Editor

PETER R. MOODY, JR.

Editorial Board

\author{
Ruth Abbey \\ University of Notre Dame \\ Shlomo Avineri \\ Hebrew University of \\ Jerusalem \\ Barry Cooper \\ University of Calgary \\ Fred Dallmayr \\ University of Notre Dame \\ John Dunn \\ Cambridge University \\ Jean Bethke Elshtain \\ University of Chicago \\ Michael A. Gillespie \\ Duke University \\ Leslie Goldstein \\ University of Delaware \\ Russell Hittinger \\ University of Tulsa \\ Axel Honneth \\ Institute for Social Research, \\ Frankfurt \\ Shozo Iijima \\ Waseda University, \\ Tokyo
}

\author{
Ramin Jahanbegloo \\ York University \\ Pierre Manent \\ L'Ecole des Hautes Etudes en \\ sciences sociales \\ Harvey C. Mansfield \\ Harvard University \\ Mary Nichols \\ Baylor University \\ Daniel Philpott \\ University of Notre Dame \\ Arlene Saxonhouse \\ University of Michigan \\ William E. Scheuerman \\ Indiana University, Bloomington \\ Steven B. Smith \\ Yale University \\ Peter Steinberger \\ Reed College \\ Vickie Sullivan \\ Tufts University \\ Jean M. Yarbrough \\ Bowdoin College
}

\section{Copyeditor: LES HARRIS \\ Editorial Interns: Nathan Sawatzky, Madeline Cronin Administrative Assistant: Kelli Brown}

\section{Former Editors}

\begin{abstract}
Waldemar Gurian
M.A. Fitzsimons

Thomas Stritch
\end{abstract}

Frederick J. Crosson

Donald P. Kommers

Walter Nicgorski

The Review of Politics publishes primarily philosophical and historical studies of politics, especially those in political theory and American political thought. The journal also includes thoughtful scholarly reflections on all aspects of politics-laws, and institutions, international relations, comparative politics-as well as literary reflections on politics or political interpretations of literature. 


\section{TABLE OF CONTENTS SPRING 2013}

Vol. 75

SPRING 2013

No. 2

John Baltes

Locke's Inverted Quarantine: Discipline, Panopticism, and the Making of the Liberal Subject . . . . . . . . . 173

Jonathan Culp

Justice, Happiness, and the Sensible Knave: Hume's

Incomplete Defense of the Just Life . . . . . . . . . . . . 193

Laura K. Field

The Philosopher Doth Protest Too Much: Rousseauian

Enlightenment and the Rhetoric of Despair . . . . . . . 221

Michael Locke McLendon

The Politics of Sour Grapes: Sartre, Elster, and

Tocqueville on Frustration, Failure, and Self-Deception . . . . 247

Reviews:

Brandon Turner: REPUBLICAN BUDS OF EMPIRE

Review of Edward G. Andrew's Imperial Republics: Revolution, War, and Territorial Expansion from the English Civil War to

the French Revolution.

Bedross Der Matossian: CONSTITUTIONALISM TO

STRENGTHEN THE STATE

Review of Nader Sohrabi's Revolution and Constitutionalism

in the Ottoman Empire and Iran . . . . . . . . . . . . . . . 273

Barry Alan Shain: DEMOCRATIC REPUBLIC, REPUBLICAN

DEMOCRACY

Review of Anthony King's The Founding Fathers v. the People:

Paradoxes of American Democracy. . . . . . . . . . . . . . 276

Cynthia R. Nielsen: FREEDOM IN COMMUNITY

Review of Nicholas Buccola's The Political Thought of Frederick

Douglass: In Pursuit of American Liberty . . . . . . . . . . . . . . . . . 279

Keith E. Whittington: COMPETITION OR CARTEL

Review of Michael S. Greve's The Upside-Down Constitution . . . . . . 282

Jacob Howland: POLITICS THROUGH THE STATESMAN

Review of Kevin Cherry's Plato, Aristotle, and the Purpose of Politics . . . . . . . . . . . . . . . . . . . . . . . . . . . . . . 285

J. Jackson Barlow: WHAT SORT OF PHILOSOPHY?

Review of Yelena Baraz's A Written Republic: Cicero's

Philosophical Politics. 
Takashi Shogimen: TURNING POINTS

Review of James Greenaway's The Differentiation of Authority:

The Medieval Turn toward Existence and Francis Oakley's

The Mortgage of the Past: Reshaping the Ancient Political

Inheritance $(1050-1300)$. . . . . . . . . . . . . . . . . . . . . . . . . . . . 289

Paul Corey: KEYS TO THE KINGDOM?

Review of Philippe Bénéton's The Kingdom Suffereth Violence:

The Machiavelli/Erasmus/More Correspondence and Other

Unpublished Documents . . . . . . . . . . . . . . . . . . . . . . . . . . . . 292

Steven Frankel: NOT THE SAME

Review of Joshua Parens's Maimonides and Spinoza: Their

Conflicting View of Human Nature . . . . . . . . . . . . . . . . . . . . . 296

Alexander S. Duff: NAVIGATING THE ABYSS

Review of Tracy B. Strong's Politics without Vision: Thinking without a Banister in the Twentieth Century . . . . . . . . . . . . . . . . . 298

Shmuel Nili: STATIST COSMOPOLITANISM

Review of Lea Ypi's Global Justice and Avant-Garde Political

Agency . . . . . . . . . . . . . . . . . . . . . . . . . . . . 301

Nina Caspersen: PEOPLE AND NATION

Review of Bernard Yack's Nationalism and the Moral

Psychology of Community . . . . . . . . . . . . . . . . . . . . . . . . . . . 304

Joseph Blenkinsopp: UNDER GOD

Review of Michael Walzer's In God's Shadow: Politics in

the Hebrew Bible . . . . . . . . . . . . . . . . . . . . . . . . . . 306

Beth A. Griech-Polelle: COMING TO RECOGNIZE

THE ENEMY

Review of Emma Fattorini's Hitler, Mussolini, and the Vatican . . . . . 309

Victoria Tin-bor Hui: UNITY AND MONARCHISM

Review of Yuri Pines's The Everlasting Empire: The

Political Culture of Ancient China and Its Imperial Legacy . . . . . . . . . 312

Sylvia Li-chun Lin: POLITICIZED DIASPORA

Review of Belinda Kong's Tiananmen Fiction outside the

Square: The Chinese Literary Diaspora and the Politics of

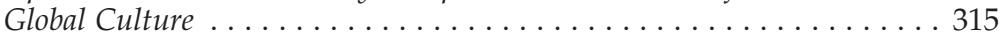

Kenneth C. Burt: ACTIVIST LIBERALISM

Review of Jonathan Bell's California Crucible: The Forging

of Modern American Liberalism . . . . . . . . . . . . . . . . . . . . . 317

Sean J. Savage: PROTRACTED WAR

Review of Brendan J. Doherty's The Rise of the President's

Permanent Campaign .......................... 320 
Subscription Information: The Review of Politics (ISSN 0034-6705) is published quarterly in February, May, August and November by Cambridge University Press, 32 Avenue of the Americas, New York, NY 10013-2473 USA/The Edinburgh Building, Shaftesbury Road, Cambridge CB2 8RU, UK for the University of Notre Dame. Annual subscription rates for Volume 75 (2013): Institutional subscription rates, print and online: US $\$ 150.00$ in the USA, Canada, and Mexico; UK $£ 87.00+$ VAT elsewhere. Institutional subscription rates, online only: US $\$ 130.00$ in the USA, Canada, and Mexico; UK $£ 75.00$ + VAT elsewhere. Institutional subscription rates, print only: US $\$ 147.00$ in the USA, Canada, and Mexico; UK $£ 85.00$ + VAT elsewhere. Individual subscription rates, print only: US $\$ 44.00$ in the USA, Canada, and Mexico; UK $£ 25.00$ + VAT elsewhere. Correspondence concerning subscriptions should be sent to: Cambridge University Press, 100 Brook Hill Drive, West Nyack, NY 10994, USA for customers in the USA, Canada, or Mexico. Customers elsewhere should contact: Cambridge University Press, The Edinburgh Building, Shaftesbury Road, Cambridge CB2 8RU, UK.

Editorial Office: All correspondence concerning submissions and manuscripts under review should be sent to The Review of Politics, University of Notre Dame, 547 Flanner Hall, Notre Dame, IN 46556. Phone: 574-631-6623. Email: ROP.Editor.1@nd.edu. Website: www.nd.edu/ rop

Abstracting and Indexing Information: Articles in The Review of Politics are indexed in the International Index to Periodicals and the Catholic Periodicals and Literature Index; abstracted in the International Political Science Abstracts; and abstracted and indexed in ABC POL. SCI., Historical Abstracts, Social Science Index (also available in the electronic versions), Book Review Index, and International Bibliography of the Social Sciences.

Copyright (C) 2013 University of Notre Dame. All rights reserved. No part of this publication may be reproduced, in any form or by any means, electronic, photocopy, or otherwise, without permission in writing from Cambridge University Press, Rights and Permissions Manager, 32 Avenue of the Americas, New York, NY 10013-2473 USA. For further information see http://us.cambridge/org/information/rights/

Periodicals postage paid in New York, NY and additional mailing offices. Postmaster: Send address changes to The Review of Politics, Cambridge University Press, 100 Brook Hill Drive, West Nyack, NY 10994-2133 USA.

Photocopying information for users in the U.S.A.: the Item-Fee Code for the publication (0034-6705/13\$9.00+.10) indicates that copying for internal or personal use beyond that permitted by Sec. 107 or 108 of the U.S. Copyright Law is authorized for users duly registered with the Copyright Clearance Center (CCC) provided that the appropriate remittance of $\$ 9.00$ per article is paid directly to CCC, 222 Rosewood Drive, Danvers, MA 01923. Specific written permission must be obtained for all other copying. 